\title{
An Assessment of the Employee Job Satisfaction: Views from Empirical Perspectives
}

\author{
Albert Tchey Agbenyegah \\ Durban University of Technology, Pietermaritzburg, South African \\ alberta@dut.ac.za
}

\begin{abstract}
Job satisfaction stresses on the personal feelings within the job environment in relation to job assessment. Various academics and scientists studied in the past, the significant association between personal expectations and job satisfaction of employees. These past studies were based on the model of personality traits and other variables in determination of employee job satisfaction. This study is to assess the relationship and effect between independent and dependent variables. To ensure that the stated objectives are met, a 7 point Likert scale questionnaires were administered to 140 managers and non-manager employees. However, only 128 of the questionnaires were returned without errors and ready to go through the analysis processes. Data analysis was conducted in two phases namely the descriptive and inferential statistics. Descriptive analysis aided by the mean counts was applied in describing the empirical data; whereas the inferential statistics of Pearson's chi-square test and ANOVA were utilized to determine the relationship and the effect of independent on the dependent variable. ANOVA was used to assess the effect of independent variables on the dependent variable. This empirical study demonstrates mix results through Pearson's chi-square and ANOVA tests. WEP and employee status does not differ from EJS whereas employee position differs from EJS. The ANOVA test revealed a significant effect of WEP and EPS on EJS. The study revealed that SME owners in FB district municipality experienced very high entrepreneurial challenges in contrast to their counterparts in JTG district municipality. Given these findings, the author called on policymakers to prepare specific strategies and programs that motivate employees within the establishment.
\end{abstract}

Keywords: Employee job satisfaction, employee status, employee working experience, job satisfaction, variables.

\section{Introduction}

Employee Job Satisfaction (EJS) is associated with variables such as the nature of tasks, managerial quality, supervisor characteristics, pay packages, promotion opportunities, organizational features and the working climate, work experience and employee salaries of the organizations (Balcı 2011: 70; Panghal and Bhambu 2013). These variables are central to the survival of the organization; thus, the responsibility is on the employer to motivate employees towards job satisfaction. According to Herzberg (1966), it is befitting that employers motivate employees for job satisfaction and productivity. Several authors have alluded to a vast number of variables that influence job satisfaction (Ahmad and Yekta 2010; Nawab and Bhatti 2011; Kord and Tamini 2012; Jeet and Sayeeduzzafar 2014). For instance, a study by Ahmad and Yekta (2010) confirmed the notion that intrinsic and extrinsic variables impact employees' job satisfaction. A similar study revealed that job satisfaction is possible in various sectors through employees' personality traits, besides the characteristics of the job (Chang and Lee 2006). Early theorists, including Mayo (1945), indicated that variables relating to sociology and psychology affect employees' work life and job satisfaction. EJS is an ongoing concern for organization's that aim to achieve their objectives.

Satisfying employees creates positive results of belonging and organizational ownership, positive well-being and personal commitment across the length and breadth of organizations (Saks 2006; Nadiri and Tanova 2010; Zeinabadi 2010). It is costly for organizations to not create a conducive workspace for employees (Tracey and Hinkin 2008). Lambert, Hogan and Barton (2001) state that organizations that are unable to guarantee employee satisfaction could trigger an exodus of employees seeking alternative employment. Nowadays various organizations operate in a poor economic climate. As such, management is unable to meet its mandate of providing goods and services with the view of satisfying its potential market share (Spagnoli, Caetano and Santos 2012). Researchers view employee retention and the ability to attract employees as vital to a successful organization (Sehunoe, Mayer and Viviers 2015). The primary focus of this empirical study was to assess the relationships and effects of different variable on EJS. EJS is referred to as the emotional state of employees towards their assigned tasks (Locke 1976; Huang, You and Tsai 2012). A study by Stander and Rothmann (2010) found that if employees are satisfied and motivated, their productivity increases. 
It is therefore paramount to determine the relationships and effects of different variables in establishing EJS. A multitude of job-related traits in humans was researched by psychologists over the years and it was found that job satisfaction is critical for the improvement of employees' societal health (Schneider and Vaught 1993). Drawing from these perceptions relating to personal commitment, it is important that employees be rewarded. The job satisfaction of employees is the focus of different variables, including economic and interpersonal activities, as well as the work climate (Herzberg 1966; Locke 1976 ). This paper focuses on some of these variables to determine their effect and relationship on EJS.

Job Satisfaction: Job satisfaction is defined as any form of enjoyment experienced by individuals in the achievement of specific tasks (Saeed et al., 2014). Robbins and Judge (2013) posit that job satisfaction focuses on the positive feelings towards a job through the motivation of employees. An earlier definition of job satisfaction by Locke (1976) referred to it as the interplay of human thoughts as expressed through the positive feelings of employees. Drawing from Locke's (1976) definition, other researchers have stated that the concept of job satisfaction could be linked to three multidimensional concepts, namely the cognitive, effective, as well as behavioral elements of individuals as they perform specific tasks (Hoppock 1935; Hulin and Judge 2003 ). A study by Kyule, Katunzi and Arasa (Kyule, Katunzi and Arasa 2016) indicated that once employees are motivated, their levels of performance increase; thus, reducing absenteeism and encouraging retention in the workplace (Sukriket 2015). Job satisfaction, according to empirical studies, emphasizes the needs of employees, while taking into consideration strategies that govern the organization in reducing the dissatisfaction of employees (Uduji 2013). Within an organization, productivity is most likely to increase if employees' behavior patterns change as a result of motivation; this, according to researchers, is linked to EJS (Yadav and Aspal 2014; Tufail, Muneer and Manzoor 2016; Tehseen and UI Hadi 2015).

Employee Job Satisfaction (EJS): EJS refers to the general state of completeness that employees experience from assigned tasks in relation to a specific job. To ensure total employee satisfaction, the onus is on employers to design the quality of processes, including the physical environment, in the organization (Celik 2008). The concept of job satisfaction entails dissimilarities between the twin terms of "inputs" and "outputs". These terms determine the exact employees' inputs for positive job outputs; hence, any output of negative results represents employees' dissatisfaction (Vishwakarma, Shukla and Nougriaya 2015 ). Other variables are connected to job satisfaction or dissatisfaction. According to Mahmoud (2008), the general expectations by the employees towards specific tasks in the organization contribute to job satisfaction. Jiang, Baker and Frazier (2009) posit that elements of poor performance levels in an organisation, standardized disorder operations and sub-standard quality products are some of the characteristics of dissatisfaction. While there is a lack of agreement on defining job satisfaction, scientific evidence indicates that through minimal process design costs and making available intrinsic payments packages to employees, job satisfaction increases (Parvin and Kabir 2011). Moreover, job satisfaction offers employees with multiple employee benefits. For example, by being satisfied with assigned tasks, the employee performs the tasks with a positive mindset, focusing on providing adequate "inputs" to increase productivity (Maher 2008).

Theoretical Framework: According to McShane and Von Glinov (2007 in MacKain et al. (2010), several theories are used to define employee satisfaction in a global context. For example, George and Jones (1999) describe job satisfaction as including variables such as societal influence, personal characteristics, and workplace characteristics and values. In the context of psychology, Meyer and Allen (1991) define job satisfaction as continued commitment, as well as normative commitment. These theories enable researchers and academics to obtain a sense of the various dimensions of job satisfaction. As a result, other variables of importance contribute to assessing the employee-employer relationship. Furthermore, the effects of variables on job satisfaction are critical. These variables are diverse in a theoretical context; thus, this study foregrounds the expectancy and equity theories. The equity theory is focused on existing conditions, and not on set standards in terms of the conditions offered to employees in exchange for any form of reward by the employer (the principle of "inputs" and "outputs" applies). Thus, employers are obliged to exercise equal treatment and motivate employees to spur the level of organisational performances. The equity theory measures employees "inputs" against the "outputs". This theory emphasizes employees' perceptions regarding fair treatments by employers (Daft and Noel 2001). One of the outstanding features of the theory is the notion that employees make comparisons about the nature of their jobs and rewards. 
The central tenet of the expectancy theory is the need for performance satisfaction of employees. According to Vroom (1964), in order for employees to be satisfied, every effort should trigger a reward in return. Thus, individual expectations in line with specific jobs are likely to increase or decrease performance. Hence, while it is known that some employees perform better based on individual returns, it is pivotal that in the end performance levels are expected to increase. The primary guiding principle of the expectancy theory entails understanding the aims of employees and the general linkages between performance and employees' efforts, the inherent reward systems, and performance and employees' desire to satisfy the goals of employees through adequate reward systems. Therefore, it is significant to measure the relationships and effects of variables on EJS. EJS is not equal, based on individuals' needs and expectations, as well as other conditions within the organisation. Drawing from past scientific evidence, the present empirical study is to assess and suggest practical solutions.

\section{Literature Review}

Work Experience: Brief (Brief 1998) suggested that job satisfaction represents different results, as well as the conditions that are expressed to form the basis to perform duties. In instances where individual job performance is good, fair compensation is demanded, with a good chance of promotion. These strings of events call for an employee to be satisfied. Variables such as the physical climate, task fulfilment and quality relationships can impact on an employee's assigned tasks despite experience (Rode 2004). The number of years employees spend in an organisation is significant to make a determination in relation to job satisfaction. The number of years spent in a job is used as the chief predictor for job satisfaction. According to Oshagbemi and Hickson (2003), working for a shorter period could lead to dissatisfaction in a specific organisation, in contrast to working for a longer period. In a similar study, Martin and Roodt (2008) found that employees show higher levels of satisfaction if more years are spent in an organisation. Sharma and Jyoti (2009) posit that employee satisfaction is minimal within the first five years in a job; however, they add that employee satisfaction increases if an individual works for over 20 years in an organisation.

Kumar and Giri (2009) concurred that there is a relationship between job satisfaction and work experience. According to the study, employees' levels of satisfaction increased if they worked for the organisation for longer periods. The study concluded that the work experience of an employee impacts positively on job satisfaction. Ercikti et al. (2011) were in agreement that among all the demographic variables, the period of years an employee worked in an organisation determines his/her job satisfaction. They, however, found that employees who were newly employed enjoyed higher job satisfaction in comparison to employees who had worked for several years. In light of the empirical and literature studies, the following null hypotheses were formulated:

$\mathbf{H}_{\mathrm{N}}$ : Working experience has no significant effect on employee satisfaction.

$\mathbf{H}_{\mathrm{N}}$ : There is no significant relationship between working experience and EJS.

Employment Status: This study categories employment status into permanent and contract employment. Throughout this study, contract and temporary employment are used interchangeably. Empirical studies have shown vast distinctions between permanent and contractual types of employment. Based on employment principles, temporary employees either enjoy negative or positive job satisfaction. Studies have revealed that employees create extra insecurity impairments that lead to dissatisfaction. Indicated, that as job insecurity worsened, the general lack of employees' well-being resulted in negative feelings towards their jobs due to dissatisfaction. These negative events in organisation harmed employer-employees' contractual relationships (Rousseau 1995). According to Davy, Kinicki and Scheck (1997), there is a significant relationship between job security and employment status. For instance, higher employee status is likely to be autonomous, challenging, and have greater responsibilities and opportunities, which implies that employees enjoy job satisfaction (Schultz and Schultz 2006). The study further found that the technical, managerial and professional status of employees attracts higher EJS, in contrast to other sectors where this was not present. However, evidence indicated that EJS differs in terms of assigned jobs rankings (Witte 1999). Scientific evidence has revealed a distinction between permanent and contract employment. Employees who are permanently employed are perceived to belong to the organisation, in contrast to contractual employees (De Cuyper, De Witte and Isaksson 2005 ). 
No matter the level of differences in the job satisfaction of employees, permanent employees are said to be periphery workers once they are allocated to contractual tasks. According to Guest et al. (Guest et al., 2006), once contractual employees realize that employers do not value their tasks in the organisation, they become dissatisfied. However, temporary employees are essential to organizations. Temporary employees are perceived as the salient assets in all forms of organisations as their contributions are valuable (Connelly, Gallagher and Gilley 2007). By inferring from empirical evidence and literature, the following null hypotheses were stated:

$\mathbf{H}_{\mathbf{N}}$ : Employee status has no significant effect on employee satisfaction.

$\mathbf{H}_{\mathbf{N}}$ There is no significant relationship between employee status and EJS.

Employee Position: Within an organisation, employees hold several positions of value. These positions are hierarchically structured in accordance with the dictates of the organisation. There is the general perception that individual positions could impact on job satisfaction (Schultz and Schultz 2006). Hancer and George (2003) concurred that there are significant linkages between an employee's position in the organisation and job satisfaction. Drawing on Herzberg's theory, it could be stated that for an individual to experience satisfaction, variables such as the content and context is of significance in making employees feel satisfied. The study further stressed that these feelings by employees in senior positions can be attributed to variables, such as the existing work climate and supervision, autonomy, responsibility, as well as higher pay packages and promotion. Employee position within an organisation is regarded as one of the variables that impact job satisfaction (Schulz 2013). In a similar study by, it was established that there are differences in terms of employee motivation and positions; the highest motivators are found in the middle and senior levels of the hierarchy, whereas non-managers are less motivated. Similarly, stated that the promotion to a higher rank within an organisation presents enormous responsibilities for aspiring employees to pursue other related tasks.

Shodhganga (2012) concurred that employees experienced more satisfaction than their peers once they assumed a higher position within an organisation. An empirical study by Kinzl et al. (2005) confirmed that high-ranking positions within an organisation are associated with job satisfaction. Furthermore, Theodossiou, Zangelidis and (2009) echoed the general sentiment that the position held by an employee in an organisation in many ways affected job satisfaction. The study further revealed that employers needed to make it possible for employees to follow career paths. According to Bates (2006), employers are expected to provide employees with senior level promotion opportunities. Drawing on the expectancy theory of, it can be said that the position held by an employee could motivate or demotivate him/her. Research by Waskiewicz (1999: 70) suggests that any position within an organisation should be designed to increase an employee's level of performance. Hence, the inability of employees to perform as expected threatened their performance. It could be viewed as a punitive measure to demotivate employees in the absence of optimum levels of performances (Van Dalen and Henkens 2013). Building on both empirical evidence and the literature review, the researcher hypothesised the null hypotheses as follows:

$\mathbf{H}_{\mathbf{N}}$ : Present position of employee has no significant effect on employee satisfaction.

$\mathbf{H}_{\mathrm{N}}$ : There is no significant relationship between present position and EJS.

The Proposed Conceptual Framework: Figure 1 below depicts the conceptual framework that directs this empirical study. This framework was based on the prior scientific work of Ivancevich. The primary aim of the framework was threefold: to support, build and test formulated hypotheses. Independent variables used in this study fell in three categories, namely Personal/Individual variables (work experience), Organisational variables (employee position), and Demographic variables (employment status). In addition, the framework illustrates the dependent variable, Employee Job Satisfaction (EJS). All these variables were operationalised and defined earlier, in line with this study. While the three independent variables mentioned may have a direct relationship and effect on EJS, their levels of weighting may differ. As such, this study postulates, as indicated through the hypotheses.

\section{Research Methodology}

The researcher designed this study to ascertain quantitative data using a structured questionnaire. This study utilised a quantitative format as the statistical tools of ANOVA and Pearson's chi-square test had to be 
conducted to either accept or reject the formulated hypotheses in line with variables, such as work experience, employee status, employee position and EJS. By gathering primary data through the quantitative method, the researcher was of the opinion that the research objectives of assessing the significant differences and the effect of the variables would be met.

Figure 1: Conceptual Framework

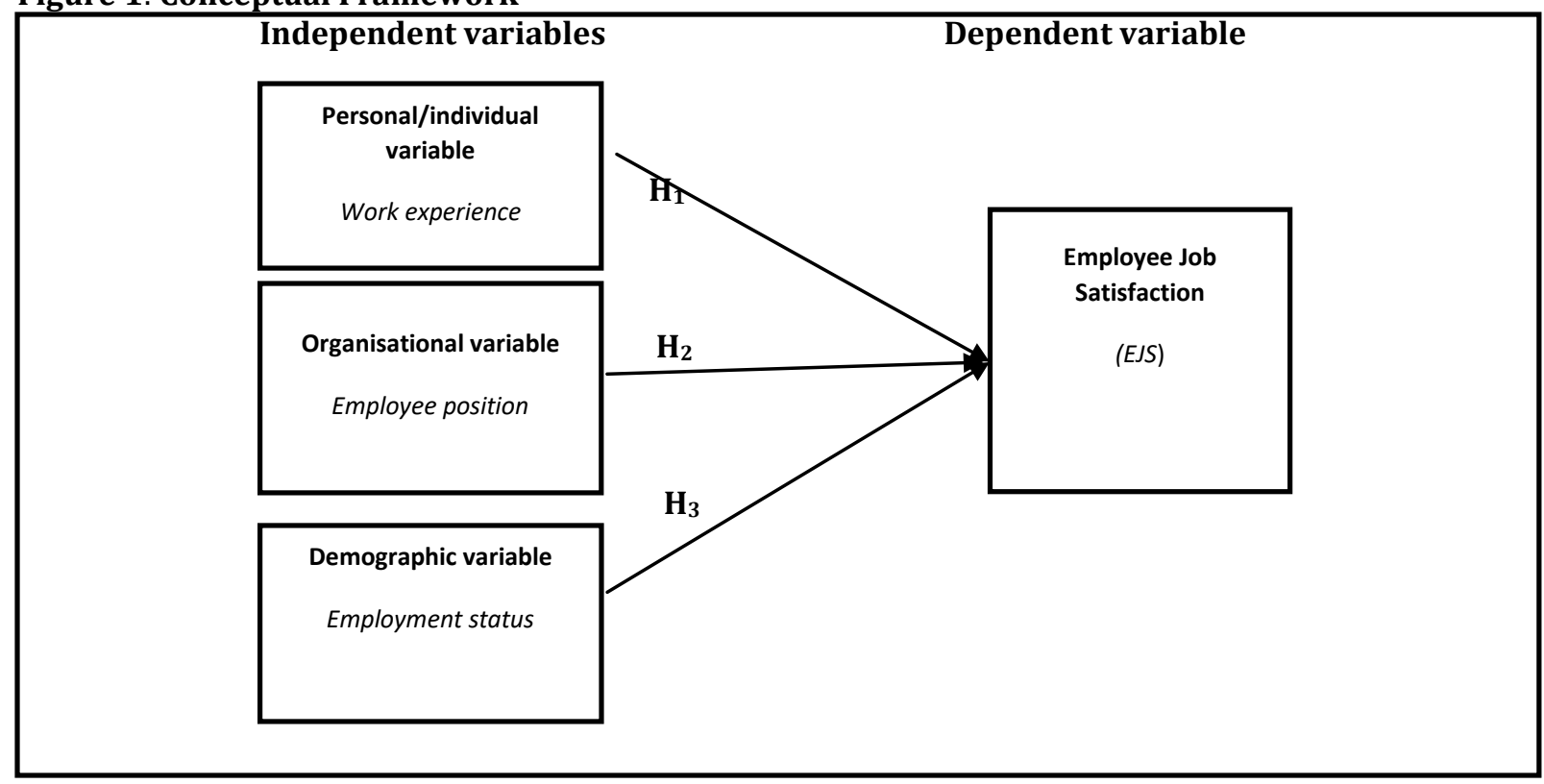

Source: Empirical study (2018)

Data Collection: The primary data for this study was gathered from respondents within organisation $\mathrm{X}$ in South Africa. The actual name of the research setting is withheld for ethical purposes. The researcher made the decision not to limit the target population for two reasons: to cover a larger group of respondents in search of credible data, and to produce a reliable and comprehensive research report. The target population consisted of permanent employees across six departments of the organisation. The justification for gathering data from only permanent employees was to allow the researcher to source primary data from the employees who were not only secure in the organization but worked under similar work conditions and enjoyed equal rights and opportunities. Due to the geographical nature of the research settings, convenience sampling technique was utilised to sample all the respondents (Blumberg, Cooper and Schindler 2011). Convenience sampling was employed to ensure that the researcher could easily access a larger group of permanent employees within a limited time frame, for a high level of anonymity, and to allow the respondents to easily complete the questionnaire at their own pace.

Research Instrument: This study was quantitative and based on previous scientific work. The author designed a 7- point Likert scale using a 25 item scale with alterations from Mehrabani and Shajari (2013) . In the end, these scales were relevant enough to gather credible primary data. To ensure that the scales fitted the present context and the research aims, the research variables were assessed through a 7-point Likert scale. The scales were ranged from (7) strongly disagree to (1) strongly agree. In total, 140 questionnaires were distributed. However, only 128 were returned without errors, with a response rate of $91 \%$. Prior to administering the research instruments, the questionnaires were piloted on a few respondents and experts (Saunders, Lewis and Thornhill 2012 ). Thereafter, the researcher made the necessary alterations for clarity. Data analysis was conducted by means of descriptive statistics using the mean values and two inferential statistics of Pearson's chi-square test and ANOVA. The reliability and consistency of the questionnaires were measured by Cronbach alpha. The Cronbach alpha was utilised to measure 25 items that yielded 0.76 and 0.84 respectively of the applicable variables. According to Sekaran and Bougie (2016), the Cronbach alpha determines a set of variables of a latent construct. Thus, the results were an indication that all the items specified on the questionnaires were reliable and consistent (Brown 2002) . 
Data Analysis and Results: For the sake of clarity and to attain the set objectives, descriptive statistics (mainly the mean values) were employed for a meaningful presentation of the empirical data set. In addition, inferential statistical tools (namely, the Pearson's chi-square test and ANOVA) were applied to assess the relationship and effect of independent and dependent variables (refer to Figure 1). The tests were in line with the principle of a "significance level of 0.05(5\%)". The null hypotheses were not accepted in cases where the pvalue yielded less than the significant level of 0.05 . Through the inferential statistics, the researcher was able to either reject or support the formulated hypotheses.

Descriptive Analysis: Different descriptions relating to the respondents in terms of biographical profiles on work experience, employees' status, and present position are shown in Tables 1, 2 and 3 below.

Table 1: Employee Satisfaction by Work Experience

\begin{tabular}{|c|c|c|c|c|c|c|c|c|}
\hline \multirow[b]{3}{*}{ Work experience } & \multirow[b]{3}{*}{$\mathbf{N}$} & \multirow[b]{3}{*}{ Mean } & \multicolumn{6}{|c|}{ 95\% $\quad$ Confidence } \\
\hline & & & & & Interva & or Mean & & \\
\hline & & & $\begin{array}{l}\text { Std. } \\
\text { Deviation }\end{array}$ & $\begin{array}{l}\text { Std. } \\
\text { Error }\end{array}$ & $\begin{array}{l}\text { Lower } \\
\text { Bound }\end{array}$ & $\begin{array}{l}\text { Upper } \\
\text { Bound }\end{array}$ & Min & Max \\
\hline$<1$ year & 3 & 30.00 & 21.284 & 12.288 & -22.87 & 82.87 & 7 & 49 \\
\hline$>1-3$ years & 40 & 19.85 & 10.812 & 1.710 & 16.39 & 23.31 & 7 & 44 \\
\hline$>4-5$ years & 42 & 16.48 & 10.322 & 1.593 & 13.26 & 19.69 & 7 & 42 \\
\hline$>6-10$ years & 25 & 23.88 & 13.252 & 2.650 & 18.41 & 29.35 & 7 & 49 \\
\hline$>10$ years & 7 & 29.14 & 11.452 & 4.328 & 18.55 & 39.73 & 13 & 42 \\
\hline
\end{tabular}

The table above indicates that employees who worked for less than one year enjoyed the highest level of job satisfaction (mean=30), while employees who worked between four and five years experienced the lowest level of job satisfaction (mean=16.48). The results from the table indicated that $42(36 \%)$ of the participants, with over four years of work experience, were less satisfied. This implied that the level of work experience did not relate or affect job satisfaction in the organization.

Table 2: Employee Satisfaction by Employee Status

\begin{tabular}{|c|c|c|c|c|c|c|c|c|}
\hline \multirow[b]{2}{*}{ Employee status } & \multirow[b]{2}{*}{$\mathbf{N}$} & \multirow[b]{2}{*}{ Mean } & \multirow[b]{2}{*}{$\begin{array}{l}\text { Std. } \\
\text { Deviation }\end{array}$} & \multirow[b]{2}{*}{$\begin{array}{l}\text { Std. } \\
\text { Error }\end{array}$} & \multicolumn{2}{|c|}{$\begin{array}{l}\text { 95\% Confidence } \\
\text { Interval for Mean }\end{array}$} & \multirow[b]{2}{*}{ Min } & \multirow[b]{2}{*}{ Max } \\
\hline & & & & & $\begin{array}{l}\text { Lower } \\
\text { Bound }\end{array}$ & $\begin{array}{l}\text { Upper } \\
\text { Bound }\end{array}$ & & \\
\hline Permanent & 80 & 19.25 & 11.884 & 1.329 & 16.61 & 21.89 & 7 & 49 \\
\hline Contract & 37 & 22.78 & 12.118 & 1.992 & 18.74 & 26.82 & 7 & 49 \\
\hline
\end{tabular}

The table above shows that among the respondents, employees on contract enjoyed the highest level of employee job satisfaction (mean=22.78), in contrast to permanent employees who enjoyed a minimal level of job satisfaction (mean=19.25).

Table 3: Employee Satisfaction by Present Position

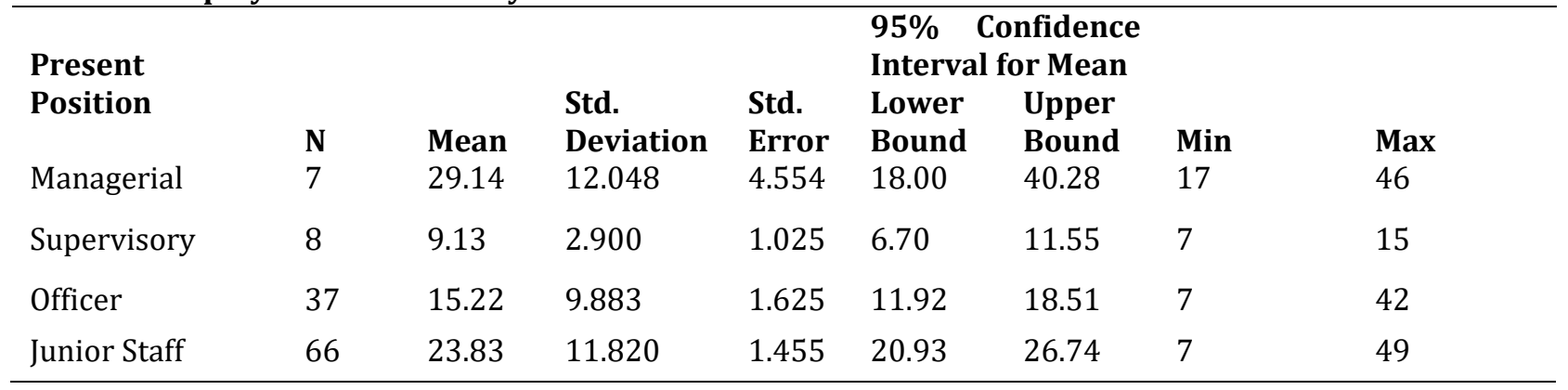


The table above shows that THE employees in managerial positions enjoyed the highest level of job satisfaction (mean=29.14). This is in sharp contrast to employees in supervisory positions, who enjoyed the lowest level of employee satisfaction (mean=9.13).

\section{Results and Discussion}

Respondents' Profile: Data was collected from various employees, from managerial to non-managerial positions. In total, 128 respondents provided empirical data. A total of $38 \%$ of the respondents were aged between 40 and 49 . The oldest age group of respondents ranged from 50 to 59 years, which represented $40 \%$ of the respondents; thus, they were the largest group of respondents in terms of age, whereas the age group ranging from 30 and 49 years represented $22 \%$ of the respondents. The majority (60\%) of the respondents had obtained a matric qualification, whereas $25 \%$ had diplomas. Only $10 \%$ of the respondents obtained university degrees, whereas 5\% held MSc degrees or PhDs. Most of the respondents (65\%), were females in contrast to $35 \%$ males. The majorities $(60 \%)$ of the females were unmarried; $10 \%$ were married. The study further showed that $20 \%$ were separated, while the remaining female employees were in serious relationships.

Testing Hypotheses: The formulated hypotheses were tested through two inferential statistical tools - the Pearson's chi-square test and ANOVA - to achieve the primary objectives of the study. This empirical study was designed to assess the relationships and effect between variables and EJS. The Pearson's chi-square test was employed to determine the significant relationships between the independent and dependent variables (refer to Figure 1). The effect of independent variables on the dependent variables was tested through the application of ANOVA. Two different groups of null hypotheses were formulated in line with the objectives. First, the Pearson's chi-square test (refer to Table 4, 5 and 6) was applied to determine the relationships between the variables. Then, the ANOVA was used to test the effect of independent variables on the dependent variable.

Table 4: Pearson's Chi-Square Test for Employee Satisfaction versus Work Experience

\begin{tabular}{lll}
\hline & & Work experience \\
Level of employee satisfaction & Chi-square & $\mathbf{1 3 , 9 7 5}$ \\
\cline { 2 - 3 } & DF & 8 \\
& P-value & 0.082 \\
\hline
\end{tabular}

A non-parametric Pearson's chi-square test was conducted to test for a significant relationship between the level of employee satisfaction and work experience at $5 \%$ level of significance. The table above indicates no significant relationship between the level of employee satisfaction and work experience at a p-value greater than 0.05 , Chi-square $(8)=13,975, p$-value $=0.082$. Thus, in this sample work experience did not differ significantly in the likelihood of the opinion of the level of employee satisfaction.

Table 5: Pearson's Chi-Square Test for Employee Satisfaction versus Employee Status

Level of employee satisfaction

Indicate your employment status

\begin{tabular}{ll} 
Chi-square & $\mathbf{1 , 0 2 9}$ \\
\hline DF & 2 \\
P-value & 0.598
\end{tabular}

A non-parametric Pearson's chi-square test was conducted to test the significant relationship between the level of employee satisfaction and employee status at 5\% level of significance. From the table above, there is no significant relationship between the level of employee satisfaction and employee status at a p-value greater than 0.05 , Chi-square (2) $=1.029$, p-value $=0.268$. Thus, in this sample employee status does not differ significantly in the likelihood on the opinion of the level of employee satisfaction. 
Table 6: Pearson's Chi-Square Test for Employee Satisfaction versus Present Position

\begin{tabular}{lll} 
& & Present position \\
Level of employee satisfaction & Chi-square & $\mathbf{1 9 , 8 0 7}$ \\
\cline { 2 - 3 } & DF & 6 \\
& P-value & 0.003 \\
\hline
\end{tabular}

A non-parametric Pearson's chi-square test was conducted to test the significant relationship between the level of employee satisfaction and the present position at a 5\% level of significance. From the table above, there is a significant relationship between the level of employee satisfaction and the present position at a pvalue less than 0.05 , Chi-square $(6)=19.807$, $p$-value $=0.003$ Thus, in this sample the present position differs significantly in the likelihood on the opinion of the level of employee satisfaction.

Testing Hypotheses: This section used the ANOVA technique to test the hypotheses to make inferences in line with the conceptual framework (Figure 1). The aim was to achieve the primary objective of determining the impact of independent variables on EJS. Tables 7, 8 and 9 below reveal how the independent variables impact on EJS.

Table 7: ANOVA Test for Effect of Employee Work Experience on EJS

\begin{tabular}{llllll}
\hline & Sum of Squares & DF & Mean Square & F & P-value \\
\hline Between Groups & 1772.226 & 4 & 443.056 & 3.345 & 0.013 \\
Within Groups & 14835.073 & 112 & 132.456 & & \\
Total & 16607.299 & 116 & & & \\
\hline
\end{tabular}

A one-way ANOVA was conducted at 5\% level of significance to test the significant effect of work experience on employee satisfaction: less than one year, one to three years, four to five years, six to ten years, and more than ten years' experience. Based on the table above, the researcher found that there was a significant effect of work experience on employee satisfaction at $\mathrm{p}<0.05$ for the five conditions [ $\mathrm{F}(4,112)=3.345, \mathrm{p}=0.013]$. The null hypothesis $\left(\boldsymbol{H}_{N}\right)$, is rejected at $5 \%$ level of significance.

Table 8: ANOVA Test for Effect of Employee Status on EJS

\begin{tabular}{llllll}
\hline & Sum of Squares & DF & Mean Square & F & p-value \\
\hline Between Groups & 315.926 & 1 & 315.926 & 2.210 & 0.140 \\
Within Groups & 16443.270 & 115 & 142.985 & & \\
Total & 16759.197 & 116 & & & \\
\hline
\end{tabular}

A one-way ANOVA was conducted at $5 \%$ level of significance to test the significant effect of employee status on employee satisfaction, and permanent and contract conditions. The table above revealed no significant effect of employee status in terms of employee satisfaction at $p>0.05$ for the two conditions $[F(1,115)=2.210$, $\mathrm{p}=0.140]$. The null hypothesis $\left(\boldsymbol{H}_{N}\right)$, is not rejected at $5 \%$ level of significance.

Table 9: ANOVA Test for Effect of Employee's Present Position on EJS

\begin{tabular}{llllll}
\hline & Sum of Squares & DF & Mean Square & F & p-value \\
\hline Between Groups & 3324.026 & 3 & 1108.009 & 9.338 & 0.000 \\
Within Groups & 13527.169 & 114 & 118.659 & & \\
Total & 16851.195 & 117 & & & \\
\hline
\end{tabular}


A one-way ANOVA was conducted at 5\% level of significance to test the significant effect of the present position of the employee on the level of employee satisfaction relating to managerial, supervisory, officer and junior staff conditions. The results as stated in the table showed a significant effect on the present position of the employee on employee satisfaction at $p<0.05$ for the four conditions $(F(3,114)=9.338, p=0.000]$. The null hypothesis $\left(\mathbf{H}_{\mathrm{N}}\right)$, is rejected at $5 \%$ level of significance. Tables 10,11 and 12 below depict the practical presentations of the research findings in line with the study objectives.

Table 10: Graphic Presentations of Empirical Findings (Descriptive Statistics)

\begin{tabular}{lll}
\hline Independent Variables & Results & Statistical/Hypotheses \\
\hline Work experience (WEP) & (less than one year) very satisfied & Mean value 30. \\
Work experience & (4 years and above) least satisfied & Mean value 16.48 \\
Employee status (EPS): Contract & Very satisfied & Mean value 22.78 \\
Employee status: Permanent & Minimal satisfaction & Mean value 19.28 \\
Employee position (EPO): Managerial & High satisfaction & Mean value 29.14 \\
Employee position: Supervisory & Least satisfied & Mean value 9.13 \\
Junior and other officers & More satisfied than supervisors & Mean value 23.83/15.22 \\
\hline
\end{tabular}

Table 11: Graphic Presentation of Empirical Findings (Pearson's Chi-square Test)

\begin{tabular}{lll}
\hline Independent variables & Results & Statistics/Hypotheses \\
\hline Work experience (WEP) & No relationship & WEP does not differ from EJS \\
Employee status & No relationship & Employee's status does not differ from EJS \\
Employee position & There is a relationship & Employee's position differs from EJS \\
\hline
\end{tabular}

Table 12: Graphic Presentations of Empirical Findings (ANOVA)

\begin{tabular}{lll}
\hline Independent Variables & Results & Statistics/Hypotheses \\
\hline Work experience & Significant effect of WEP on EJS & $\begin{array}{l}\mathbf{H}_{\mathbf{n}} \text { : Is rejected at 5\% level of significance } \\
\text { Employee status (EPS) }\end{array}$ \\
$\begin{array}{ll}\mathbf{H}_{\mathbf{n}} \text { : Is not rejected at 5\% level of } \\
\text { significance } \\
\text { Employee position (EPO) }\end{array}$ & Significant effect of EPO on EJS & $\mathbf{H}_{\mathbf{n}}$ : Is rejected at 5\% level of significance \\
\hline
\end{tabular}

Discussion of Results: The study sought to assess the significant relationships and effects between independent variables (work experience, employee status and position) and the dependent variable (EJS). Employee satisfaction in organisations differs. Job satisfaction, in general, depends on several variables. However, despite difficult working conditions, employees are expected to perform in line with employees' expectations to meet set objectives. To ensure employees are satisfied, this empirical study utilised two inferential statistical tools; namely, Pearson's chi-square test and ANOVA, to conduct the statistical analysis. Regarding the socio-demographic profile of the participants, the study showed that $40 \%$ were in the age group ranging from 50 to 59 years, $38 \%$ were aged 40 years and above, while $22 \%$ were aged between 30 and 49 years. The participants' age in this study cannot be overlooked as every participant's age relates to specific needs and expectations in line with social needs, as well as conditions of employment. Literature indicates that the age of participants plays a significant role in EJS. For instance, the U-shaped theory of Clark (1997) indicates the relationship between EJS and the lifespan of employees. The theory further adds that older employees are more satisfied in contrast to younger employees in an organisation. The management must endeavour to increase the level of employee satisfaction; if employees are satisfied in their jobs, employee turnover will decrease as employees gain more experience in the organisation with a resultant effect on productivity. Results in terms of academic achievements showed that $65 \%$ of the respondents had matric qualifications, $25 \%$ obtained diplomas, while $5 \%$ held university degrees, and another $5 \%$ obtained MSc degrees and PhDs. To a certain extent, this result indicates a high level of literacy in the organisation.

This finding is consistent with a study by (Hoy and Musker 1987) which indicated that highly qualified employees are better positioned to find better employment and experienced sufficient satisfaction in contrast to less qualified employees. Most of the respondents were females, with the majority (60\%) not being married. Ten percent were married and $20 \%$ were separated. The result implied that the most of the respondents did not have could concentrate on their jobs as most of them were unmarried. A total of 70 
$(60 \%)$ of the matric certificate holders were employed in permanent positions, while 47 (40\%) held contract appointments in the organisation. The empirical outcomes of this study showed that the null hypotheses for employee experience $\left(\mathrm{H}_{\mathrm{N}} 1\right)$ employment status $\left(\mathrm{H}_{\mathrm{N}} 2\right)$ and employee position $\left(\mathrm{H}_{\mathrm{N}} 3\right)$ were inconclusive as two null hypotheses are accepted and only one is rejected. Through the ANOVA technique, it was found that there is a significant effect of two key independent variables out of the three variables earmarked for the study. The independent variables are work experience and employees in a permanent position. The findings are inconsistent with a study by Oshagbemi and Hickson (2003) that employees who worked in organisations for a few years were highly dissatisfied in contrast to those who worked for a longer period in organisations.

\section{Conclusion and Recommendations}

This empirical study was designed to assess the relationships between work experience, employee position and employee status, and the dependent variable of EJS. Specifically, the study sought to determine whether there was a significant effect between independent and dependent variables. To contextualize this study, an extensive literature search was conducted on the various independent variables, such as work experience, employee position and employment status. Through the literature review, broader insights on the research phenomenon were obtained, with more focus on the dependent EJS. At the same time, related gaps in the existing literature were uncovered. Inferences from the primary data were possible through two statistical tools - the ANOVA and Pearson's chi-square test. Having completed the analysis, the study revealed that the dependent variable of EJS did not support the two independent variables of WEP and employee status. Moreover, no relationship existed between the variables. However, there was a relationship between employee position and EJS. The ANOVA statistical tool, based on the formulated hypotheses, showed mix findings in terms of the dependent variable of EJS, as well as the independent variables of EPS, WEP and EPO.

Two variables, WEP and EPO, were found to have a significant effect on EJS, whilst EPS did not have a significant effect. Hence, two null hypotheses were rejected. Only one was accepted, as indicated in Table 12. Given the rural nature of the study area, these results were of significance as they indicated the effect and relationship of independent variables on EJS. The mean results (Table 10) of the independent variables were discussed. The findings pointed to high levels of dissatisfaction among junior employees, including those in managerial positions. Based on these findings, the following recommendations were made to enhance EJS. Provision of a well-structured system of recognition and rewards (rewards could be non-monetary or monetary). Management needs to institute employees' assistance programmes (EAPs) to offer tailored-made support to employees in supervisory positions across departments. The EAPs should focus on the training needs of each employee in relation to his/her job description. The establishment of mentor programmes must be instituted to strengthen the subordinate-supervisor relationship. The establishment of an employee participation forum (EPF) across the organisation to involve employees to discuss issues that impact negatively on their performance.

Implications: Given the high demand for job satisfaction by employees, the onus is on employers to identify variables that impact on EJS in their organisation. Once the level of impact is determined whether negative or positive, policymakers and managers need to craft tailored-made strategies and programmes to motivate their employees. These programmes and policies are desirable as job satisfaction within an organisation increases employees' performance and ensures that the organisation's stated objectives are met. Furthermore, this finding can be utilised as a key input in formulating strategies towards establishing workable policies in the organisation. EPF could increase individuals' autonomy and controls of their personal lives, motivate them, increase their commitment to the organisation, and stimulate productivity. EPFs enable employees to become active participants in decision-making processes.

\section{Acknowledgements}

Compelling Interest: There was no inappropriate financial or personal interest on the part of the author in preparing this empirical study.

Author's Contributions: The author designed this study and developed it; assistance was sought from a statistician, L.S., to analyse the primary data. 


\section{References}

Ahmad, Z. A. \& Yekta, Z. A. (2010). Relationship between perceived organizational support, leadership behavior, and job satisfaction: An empirical study in Iran. Intangible Capital, 6 (2), 162-184.

Balcl, F. (2011). The effects of education on police officer job satisfaction: a case of Turkish national police. International Journal of Human Science, 8(2), 265-285.

Bates, W. R. (2006). An investigation into the work environment elements on job satisfaction-a case study on a company in the telecommunications industry. University of Johannesburg.

Blumberg, B., Cooper, D. R. \& Schindler, P. S. (2011). Business Research Methods. London: McGraw-Hill.

Brief, A. P. (1998). Attitudes in and around organizations. Sage.

Brown, J. D. (2002). The Cronbach alpha reliability estimate. JALT Testing \& Evaluation SIG Newsletterrode, 6 (1).

Celik, C. (2008). Relationship of organizational commitment and job satisfaction: A field study of tax office employees.

Chang, S. C. \& Lee, M. S. (2006). Relationships among personality traits, job characteristics, job satisfaction and organizational commitment-an empirical study in Taiwan. The Business Review, 6(1), 201-207.

Clark, A. E. (1997). Job satisfaction and gender: Why are women so happy at work? Labour Economics, 4, 341372.10.1016/S0927-5371(97)00010-9.

Connelly, C. E., Gallagher, D. G. \& Gilley, K. M. (2007). Organizational and client commitment among contracted employees: A replication and extension with temporary workers. Journal of Vocational Behavior, 70 (2), 326-335.

Daft, R. L. \& Noel, R. A. (2001). Organisational Behaviour. New York: South-Western Publishing.

Davy, J. A., Kinicki, A. J. \& Scheck, C. L. (1997). A test of job security's direct and mediated effects on withdrawal cognitions. Journal of Organizational Behavior: The International Journal of Industrial, Occupational and Organizational Psychology and Behavior, 18(4), 323-349.

De Cuyper, N., De Witte, H. \& Isaksson, K. (2005). Temporary employment in Europe: Conclusions. In: De Cuyper, N., Isaksson, K. and De Witte, H. eds. Employment contracts and well-being among European workers. Hampshire, 225-244.

Ercikti, S., Vito, G. F., Walsh, W. F. \& Higgins, G. E. (2011). Major Determinants of Job Satisfaction Among Police Managers. Southwest Journal of Criminal Justice, 8(1).

Guest, D. E., Oakley, P., Clinton, M. \& Budjanovcanin, A. (2006). Free or precarious? A comparison of the attitudes of workers in flexible and traditional employment contracts. Human Resource Management Review, 16(2), 107-124.

Hancer, M. \& George, R. T. (2003). Job satisfaction of restaurant employees: An empirical investigation using the Minnesota Satisfaction Questionnaire. Journal of Hospitality \& Tourism Research, 27(1), 85-100.

Herzberg, F. (1966). Work and the nature of man, Cleveland World Publishing Co.

Hoppock, R. (1935). Job satisfaction, Harper and Brothers, New York, 47.

Hoy, W. \& Musker, C. (1987). Educational administration: theory, research and practice. 3rd. ed. New York: Random House.

Huang, C. C., You, C. S. \& Tsai, M. T. (2012). A multidimensional analysis of ethical climate, job satisfaction, organizational commitment, and organizational citizenship behaviors. Nursing Ethics, 19(4), 513529.

Hulin, C. L. \& Judge, T. A. (2003). Job attitudes. In: Borman, W. C., Liken, D. R. and Klimoski, R. J. eds. Handbook of psychology: industrial and organisational psychology. Hoboken, NJ: Wiley, 255-276.

Jeet, V. \& Sayeeduzzafar, D. (2014). A study of HRM practices and its impact on employees job satisfaction in private sector banks: A case study of HDFC Bank. International Journal of Advance Research in Computer Science and Management Studies, 2(1), 62-68.

Jiang, B., Baker, R. C. \& Frazier, G. V. (2009). An analysis of job dissatisfaction and turnover to reduce global supply chain risk: Evidence from China. Journal of operations management, 27(2), 169-184.

Kinzl, J., Knotzer, H., Traweger, C., Lederer, W., Heidegger, T. \& Benzer, A. (2005). Influence of working conditions on job satisfaction in anaesthetists. British Journal of Anaesthesia, 94(2), 211-215.

Kord, B. \& Tamini, B. K. (2012). A cross-cultural study of job satisfaction and organizational commitment of bank employees in Iran and India. Apeejay Journal of Management and Technology, 7(1), 13-18.

Kumar, P. \& Giri, V. N. (2009). Effects of age and experience on job satisfaction and organizational commitment. The Icfai University of Organizational Behavior, 8(1), 28-36. 
Kyule, A. K., Katunzi, T. \& Arasa, R. (2016). The moderating effect of remuneration on the relationship between work-life policies and employee work outcomes among lecturers in Kenya. Nairobi:

Lambert, E. G., Hogan, N. L. \& Barton, S. M. (2001). The impact of job satisfaction on turnover intent: a test of a structural measurement model using a national sample of workers. The Social Science Journal, 38(2), 233-250.

Locke, E. A. (1976). The nature and causes of job satisfaction. In: Dunnette, M. D. ed. Handbook of Industrial and Organisational Psychology. Chicago, IL: Rand McNally.

MacKain, S. J., Myers, B., Ostapiej, L. \& Newman, R. A. (2010). Job satisfaction among psychologists working in state prisons: The relative impact of facets assessing economics, management, relationships, and perceived organizational support. Criminal Justice and Behavior, 37(3), 306-318.

Maher, D. (2008). Interactive whiteboards and web conferencing systems in the primary school. Educational Research at Macquarie, 3, 30-31.

Mahmoud, A. (2008). A study of nurses' job satisfaction: the relationship to organizational commitment, perceived organizational support, transactional leadership, transformational leadership, and level of education. European journal of scientific research, 22(2), 286-295.

Martin, A. \& Roodt, G. (2008). Perceptions of organisational commitment, job satisfaction and turnover intentions in a post-merger South African tertiary institution. SA Journal of Industrial Psychology, 34(1), 23-31.

Mayo, E. (1945). The Social Problems of an Industrial Civilization. Boston: School of Business Administration, Harvard University.

Mehrabani, S. E. \& Shajari, M. (2013). Relationship between employee empowerment and employee effectiveness. Service Science and Management Research, 2(4), 60-68.

Meyer, J. P. \& Allen, N. J. (1991). A three-component conceptualization of organizational commitment. Human resource management review, 1(1), 61-89.

Nadiri, H. \& Tanova, C. (2010). An investigation of the role of justice in turnover intentions, job satisfaction, and organizational citizenship behavior in hospitality industry. International Journal of Hospitality Management, 29(1), 33-41.

Nawab, S. \& Bhatti, K. K. (2011). Influence of employee compensation on organizational commitment and job satisfaction: A case study of educational sector of Pakistan. International Journal of Business and Social Science, 2(8)

Oshagbemi, T. \& Hickson, C. (2003). Some aspects of overall job satisfaction: A binomial logit model. Journal of Managerial Psychology, 18(4), 357-367.

Panghal, S. \& Bhambu, S. (2013). Factors influencing job satisfaction of banking sector employees in India. International Journal of New Innovations in Engineering and Technology, 1(3), 41-44.

Parvin, M. M. \& Kabir, M. N. (2011). Factors affecting employee job satisfaction of pharmaceutical sector. Australian Journal of business and management research, 1(9), 113.

Robbins, S. \& Judge, T. (2013). Organisational behavior 15th ed. Boston.: Pearson.

Rode, J. C. (2004). Job satisfaction and life satisfaction revisited: A longitudinal test of an integrated model. Human relations, 57(9),1205-1230.

Rousseau, D. (1995). Psychological contracts in organizations: Understanding written and unwritten agreements. Sage Publications.

Saeed, I., Waseem, M., Sikander, S. \& Rizwan, M. (2014). The relationship of turnover intention with job satisfaction, job performance, leader-member exchange, emotional intelligence and organizational commitment. International Journal of Learning and Development, 4(2), 242-256.

Saks, A. M. (2006). Antecedents and consequences of employee engagement. Journal of managerial psychology, 21(7), 600-619.

Saunders, M., Lewis, P. \& Thornhill, A. (2012). Research methods for business students. . New York: : Prentice Hall.

Schneider, D. S. \& Vaught, B. C. (1993). A comparison of job satisfaction between public and private sector managers. Public Administration Quarterly, 68-83.

Schultz, D. \& Schultz, S. E. (2006). Psychology and Work Today. 9th ed. New Jersey: Pearson Education Inc.

Schulz, J. (2013). The impact of role conflict, role ambiguity and organizational climate on the job satisfaction of academic staff in research-intensive universities in the UK. Higher Education Research \& Development, 32(3), 464-478. 
Sehunoe, N., Mayer, C. H. \& Viviers, R. (2015). Job satisfaction, organisational commitment and work engagement in an insurance company. South African Journal of Labour Relations, 39(2), 123-144.

Sekaran, U. \& Bougie, R. (2016). Research methods for business: A skill building approach. John Wiley \& Sons.

Sharma, R. \& Jyoti, J. (2009). Job Satisfaction Of University Teachers: An Empirical Study. Journal of Services Research, 9(2).

Shodhganga. (2012). Job Satisfaction.

Spagnoli, P., Caetano, A. \& Santos, S. C. (2012). Satisfaction with job aspects: Do patterns change over time? Journal of Business Research, 65(5), 609-616.

Stander, M. W. \& Rothmann, S. (2010). The relationship between leadership, job satisfaction and organisational commitment. South African Journal of Human Resource Management, 6(3), 7-13.

Sukriket, P. (2015). The relationship between job satisfaction and turnover intention of Thai software programmers in Bangkok. . AU Journal of Management, 12(2), 42-52

Tehseen, S. \& UI Hadi, N. (2015). Factors influencing teachers' performance and retention. Mediterranean Journal of Social Sciences, 1, 233-244.

Theodossiou, L. \& Zangelidis, A. (2009). Career prospects and tenure job satisfaction proÖles: evidence from panel data. Journal of Socio-Economics, 38(4), 648-657.

Tracey, J. B. \& Hinkin, T. R. (2008). Contextual factors and cost profiles associated with employee turnover. Cornell Hospitality Quarterly, 49, 12-27.

Tufail, M. S., Muneer, S. \& Manzoor, M. (2016). How Organizational Rewards And Organizational Justice Affect The Organizational Citizenship Behavior And Counterproductive Work Behavior: Analysis Of Pakistan Service Industries. City University Research Journal, 171-182.

Uduji, J. I. (2013). Hygiene factors: The foundations for heightening the marketing executives motivation in the banking industry in Nigeria. European Journal of Business and Management, 5(15),68-75.

Van Dalen, H. P. \& Henkens, K. (2013). Dilemmas of downsizing during the Great Recession: Crisis strategies of European employers. De Economist, 161(3), 307-329.

Vishwakarma, R. K., Shukla, A. \& Nougriaya, S. (2015). Job satisfaction and its impact on absenteeism: A case study related to teachers in Private Engineering colleges. International Journal of Engineering Technology \& Management Research, 3(1), 10-15.

Waskiewicz, S. P. (1999). Variables That Contribute to Job Satisfaction in Secondary School Assistant Principals. Virginia Tech.

Witte, H. D. (1999). Job insecurity and psychological well-being: Review of the literature and exploration of some unresolved issues. European Journal of work and Organizational psychology, 8(2), 155-177.

Yadav, P. \& Aspal, J. (2014). Importance of job satisfaction and talent management. International Journal of Research in IT and Management, 4(7), 55-65.

Zeinabadi, H. (2010). Job satisfaction and organizational commitment as antecedents of organizational citizenship behavior (OCB) of teachers. Procedia-Social and Behavioral Sciences, 5, 998-1003. 